\title{
Czynniki materiałowe w badaniach penetracyjnych - czas wywoływania
}

\author{
Material factors in liquid-penetrant inspection in relation \\ to development time
}

\section{Streszczenie}

W artykule przedstawiono wyniki badań wpływu rodzaju materiału, chropowatości powierzchni w miejscu niezgodności oraz szerokości niezgodności na czas wywoływania w badaniach penetracyjnych. Wynikiem jest funkcja, która omawia w jakim stopniu poszczególny czynnik materiałowy wpływa na czas wywoływania. Oprócz wyników na blachach modelowych przedstawiono także wyniki z badań praktycznych pęknięć naturalnych.

Słowa kluczowe: niezgodność, wada, badania penetracyjne, adhezja

\begin{abstract}
In the paper it has been presented the results of investigations into the influence of the material kind, surface roughness in the imperfection place and the imperfection width on the development time in liquidpenetrant testing. The investigations result is the function which describes how far the individual material factor affects the development time. Apart from the results obtained on model sheets it has been given also the results of practical testing of natural cracks.
\end{abstract}

Keywords: imperfection, defect, penetration testing, adhesion

\section{Wstęp}

Metoda penetracyjna ma zastosowanie do wszystkich materiałów, a jej jedynym ograniczeniem jest porowatość badanego materiału. Literatura i stosowane normy europejskie określają czas wywoływania (czas wyjścia penetrantu z nieciągłości na powierzchnie) od 10 do 30 minut, nie uwzględniając rodzaju materiału. Praktyka natomiast pokazuje, iż czas wywoływania jest ściśle związany z rodzajem materiału i waha się od kilku minut do 24 godzin. Literatura opisuje tylko oddziaływania ze strony penetrantu, natomiast nie opisuje oddziaływania od strony materiału, czyli wpływu na adhezję pomiędzy penetrantem a materiałem badanym czynników związanych z materiałem. Dlatego wykonano badania mające na celu przybliżenie tej tematyki. Określenie, które czynniki materiałowe i w jakim stopniu wpływają na czas wywoływania, może okazać się bardzo pomocne w praktyce badawczej, w celu dobrania prawidłowego czasu wywoływania [1 $\div 4]$.

Wpływ wybranych materiałów został sprawdzony w niniejszej pracy, a jego wynik odzwierciedla miarę adhezji między penetrantem a materiałem zwilżanym. Na podstawie literatury stwierdzono, iż chropowatość powierzchni także wpływa na adhezję. Zatem chropowatość powierzchni to kolejny czynnik materiałowy, który został poddany badaniom. Przewidywano także, że na czas wywoływania może wpływać objętość penetrantu w nieciągłości. W tym celu szerokość nieciągłości także została uwzględniona w badaniu. Przedmiotem badań było zatem określenie czasów wywoływania (zmienna zależna) dla podstawowych materiałów konstrukcyjnych oraz wpływu na ten czas poszczególnych czynników (zmienne niezależne) takich, jak: rodzaj materiału, chropowatość powierzchni w miejscu niezgodności oraz szerokość niezgodności.

\section{Badania praktyczne}

Wybrane materiały do badań to stal konstrukcyjna S355J2C+N, stop aluminium AlSi1MgMn i nikiel Nickel 200. W celu sprawdzenia wpływu zmiennych niezależnych na zmienną zależną, zrealizowano doświadczenie z zastosowaniem zrandomizowanego frakcyjnego planu czynnikowego dla zmiennych, którym przyporządkowano trzy poziomy wartości. Plan badań zakładał, że każda ze zmiennych zostanie zbadana na jednym z trzech poziomów: dolnym, środkowym i górnym (tabl. I).

Aby wyznaczyć poziomy wartości dla poszczególnych czynników, utworzono złącza spawane z każdego z badanych materiałów, z naturalnymi pęknięciami. Pierwszym krokiem było przypisanie szerokości nieciągłości do poszczególnych poziomów. W tym celu utworzone pęknięcia na badanych materiałach zostały sfotografowane na mikroskopie stereoskopowym Olympus SZX9 przy powiększeniu

Dr inż. Paweł Irek - Instytut Spawalnictwa, Ośrodek Kształcenia i Nadzoru Spawalniczego.

Autor korespondencyjny/Corresponding author. pawel.irek@onet.pl 
4x i 28,5x. Na podstawie zdjęć dokonano pomiarów szerokości pęknięć przy pomocy programu Auto CAD 2012. Dokładność pomiaru wynosiła $4 \mu \mathrm{m}$. Liczba pomiarów dla każdego pęknięcia była różna, gdyż pomiar szerokości pęknięcia był wykonywany w odstępach wynoszących 1 milimetr. Zatem liczba pomiarów dla każdego pęknięcia, zależnie od jego długości, wynosiła od kilku do ponad 100 pomiarów. Zakres szeroko- ści zmierzonych pęknięć wszystkich materiałów badanych mieści się w przedziale $4 \div 1228 \mu \mathrm{m}$. O ile dla stali konstruk- cyjnej i niklu zakres szerokości pęknięć okazał się zbliżony, to dla aluminium był on ponad dwukrotnie mniejszy. Dlatego zakres szerokości pęknięć przyjęty do badań został uśredniony, ale także tak, aby obejmował cały zakres szerokości nieciągłości (tabl. III). Dolny poziom wartości wynosi 50 $\mu \mathrm{m}$, ze względu na ograniczenia szczelinomierza płytkowego.

Kolejnym etapem w celu przypisania wartości poszczególnych poziomów był pomiar profilu chropowatości. W tym celu wykonane złącza przełamano w miejscu utworzonych pęknięć, tak aby wykonać pomiary profilu chropowatości. Do tego celu skompletowano stanowisko do badań profilu chropowatości, w którym program komputerowy Turbo Datawin-NT jest zintegrowany z profilometrem stykowym Hommel tester T1000. Zmierzony zakres chropowatości powierzchni pęknięć mie- ścił się w przedziale: 1,39 $\div 13,24$. Chropowatość powierzchni pęknięć w stali konstrukcyjnej oscylowała wokół zbliżonego poziomu i mieściła się w zakresie: $3,70 \div 7,51$. Największym zakresem chropowatości powierzchni pęknięć odznaczał się stop aluminium i wynosił on: $2,01 \div 13,24$. Natomiast chropo- watość powierzchni pęknięć w badanym gatunku niklu cecho- wała się najmniejszymi wartościami chropowatości i mieściła się w zakresie:

Tablica I. Czynniki poddane badaniu i przypisane im poziomy Table I. Factors subjected to testing and the levels assigned to them

\begin{tabular}{|c|c|c|c|}
\hline \multirow{2}{*}{$\begin{array}{c}\text { Poziom } \\
\text { czynnika }\end{array}$} & \multicolumn{3}{|c|}{ Proces: czas wywoływania } \\
\cline { 2 - 4 } & \multicolumn{3}{|c|}{ Czynniki poddane badaniu } \\
\hline $\begin{array}{c}\text { Zmienne } \\
\text { niezależne }\end{array}$ & $\begin{array}{c}\text { Rodzaj } \\
\text { materiału }\end{array}$ & $\begin{array}{c}\text { Chropowatość } \\
\text { powierzchni }\end{array}$ & $\begin{array}{c}\text { Szerokość } \\
\text { nieciągłości }\end{array}$ \\
\hline Poziom dolny & $\mathrm{x}_{1}$ & $\mathrm{y}_{1}$ & $\mathrm{z}_{1}$ \\
\hline $\begin{array}{c}\text { Poziom } \\
\text { środkowy }\end{array}$ & $\mathrm{x}_{2}$ & $\mathrm{y}_{2}$ & $\mathrm{z}_{2}$ \\
\hline $\begin{array}{c}\text { Poziom górny } \\
\text { Poziom }\end{array}$ & $\mathrm{x}_{3}$ & $\mathrm{y}_{3}$ & $\mathrm{z}_{3}$ \\
\hline
\end{tabular}

Tablica II. Czynniki poddane badaniu i przypisane im poziomy Table II. Factors subjected to testing and the levels assigned to them

\begin{tabular}{|c|c|c|c|c|}
\hline \multirow{2}{*}{ Lp. } & \multirow{2}{*}{$\begin{array}{l}\text { Oznaczenie } \\
\text { elementu }\end{array}$} & \multirow{2}{*}{$\begin{array}{l}\text { Oznaczenie } \\
\text { otworów } \\
\text { w elemencie }\end{array}$} & \multicolumn{2}{|c|}{$\begin{array}{c}\text { Nominalne wymiary } \\
\text { otworów }\end{array}$} \\
\hline & & & $\begin{array}{l}\text { średnica } \\
\text { „d", mm }\end{array}$ & $\begin{array}{l}\text { głębokośćc } \\
\text { „h”, mm }\end{array}$ \\
\hline 1 & \multirow{3}{*}{ STAL } & 1 & 1,25 & \multirow{9}{*}{1,25} \\
\hline 2 & & 2 & 1,50 & \\
\hline 3 & & 3 & 1,75 & \\
\hline 4 & \multirow{3}{*}{$\begin{array}{c}\text { STOP } \\
\text { ALUMINIUM }\end{array}$} & 1 & 1,25 & \\
\hline 5 & & 2 & 1,50 & \\
\hline 6 & & 3 & 1,75 & \\
\hline 7 & \multirow{3}{*}{ NIKIEL } & 1 & 1,25 & \\
\hline 8 & & 2 & 1,50 & \\
\hline 9 & & 3 & 1,75 & \\
\hline
\end{tabular}

1,39 7,40. Poziomy chropowatości dobrano tak, aby objąć cały zakres chropowatości (tabl. III).

Przed przełamaniem złączy wykonano badania penetracyjne. Wyniki przedstawia rysunek 1 .

Średnie czasy wywoływania dla różnych materiałów pokazują znaczące różnice w czasie wywoływania dla poszczególnych materiałów. Dla niklu czas wywoływania jest około dwukrotnie dłuższy niż dla stopu aluminium i pięciokrotnie dłuższy niż dla stali konstrukcyjnej. W celu przypisania wartości czynnikowi związanemu z rodzajem materiału (rodzaj materiału) należało wykonać dodatkowe badania. Badania te miały na celu wyeliminować podczas badań wpływ chropowatości niezgodności i jej objętość na różnice w czasach wywoływania pomiędzy poszczególnymi materiałami. W tym celu wykonano próbki z stali, aluminium i niklu. W próbkach przeznaczonych do badań wykonano nieprzelotowe otwory symulujące pory powierzchniowe o tych samych wymiarach, co w poszczególnych płytkachz różnych materiałów. Dla optymalizacji przebiegu procesu badania penetracyjnego ze względu na możliwości psychofizyczne operatora oraz ze względu na dokładność pomiarową wskazań, w każdym elemencie wykonano tylko 3 otwory. Nominalne wymiary otworów zestawiono w tablicy II.

Następnie wykonano serię badań penetracyjnych porównując przy tym czasy wywoływania dla otworów o tych samych wymiarach lecz w różnych materiałach. Średnie czasy wywoływania dla tych samych otworów lecz w różnych materiałach obrazuje rysunek 2 .

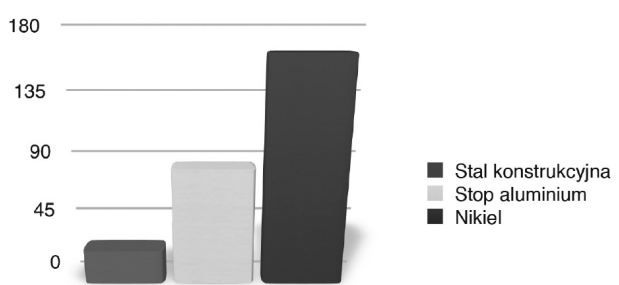

Rys. 1. Średnie czasy wywoływania dla badanych materiałów Fig. 1. Average development times for tested materials

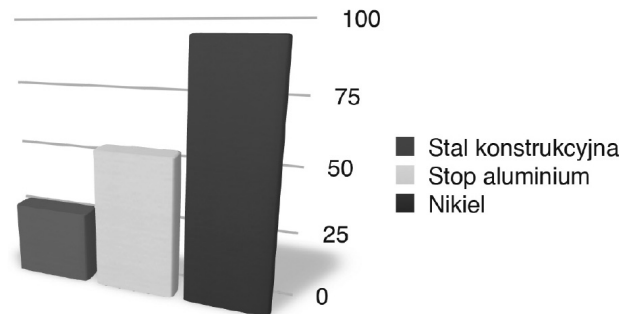

Rys. 2. Średnie czasy wywoływania dla otworów o tych samych wymiarach lecz $w$ różnych materiałach konstrukcyjnych

Fig. 2. Average development time for holes the same in dimensions but made in different constructional materials

Tablica III. Czynniki poddane badaniu i przypisane im poziomy wartości Table III. Factors subjected to testing and the levels assigned to them

\begin{tabular}{|c|c|c|c|}
\hline $\begin{array}{c}\text { Poziom } \\
\text { czynnika }\end{array}$ & \multicolumn{3}{|c|}{ Proces: czas wywoływania } \\
\cline { 2 - 4 } $\begin{array}{c}\text { Zmienne } \\
\text { niezależne }\end{array}$ & $\begin{array}{c}\text { Rodzaj } \\
\text { materiału }\end{array}$ & $\begin{array}{c}\text { Chropowatość } \\
\text { powierzchni Ra, } \\
\mu \mathrm{m}\end{array}$ & $\begin{array}{c}\text { Szerokość } \\
\text { nieciągłości, } \\
\mu \mathrm{m}\end{array}$ \\
\hline Poziom dolny & 1 & 1 & 50 \\
\hline $\begin{array}{c}\text { Poziom } \\
\text { środkowy }\end{array}$ & 1,92 & 5 & 500 \\
\hline Poziom górny & 3,4 & 10 & 1000 \\
\hline
\end{tabular}




\section{Badania pęknięć modelowych}

Po przypisaniu każdej zmiennej trzech poziomów utworzono plan czynnikowy (tabl. IV).

Do utworzonego planu czynnikowego wykonano blachy modelowe z badanej stali, stopu aluminium i niklu o grubości $6 \mathrm{~mm}$, których powierzchnia czołowa miała chropowatość na poziomie dolnym, środkowym i górnym. Chropowatość powierzchni czołowych blach modelowych była zbliżona w kierunku poprzecznym, jak i wzdłużnym, tak jak ma to miejsce w pęknięciach. Żądane wartości chropowatości uzyskano dzięki obróbce strumieniowo-ściernej. Blachy modelowe tworzyły pomiędzy sobą szczelinę o wartości 50, 500 i $1000 \mu \mathrm{m}$ (rys. 3).

Dzięki bocznym śrubom regulowana była szerokość szczeliny, a jej wielkość mierzona była za pomocą szcze- linomierza płytkowego. Na tak przygotowane blachy mo- delowe nakładano za pomocą pędzla penetrant. Wśród wyników rejestrowano najmniejszą i największą szerokość wskazania (rys. 4) w odstępach czasowych aż do ustania rozwoju wskazań.

\section{Wyniki badań i analiza}

Na tak przygotowanych blachach modelowych wykonano badania penetracyjne zgodnie z planem czynnikowym. Czas penetracji ustalono na 30 minut dla stali i aluminium, a niklu 120 minut, na podstawie wcześniejszych badań. Badania powtórzono 3 razy, a wyniki uśredniono. Uzyskane końcowe wyniki przedstawia tablica V.

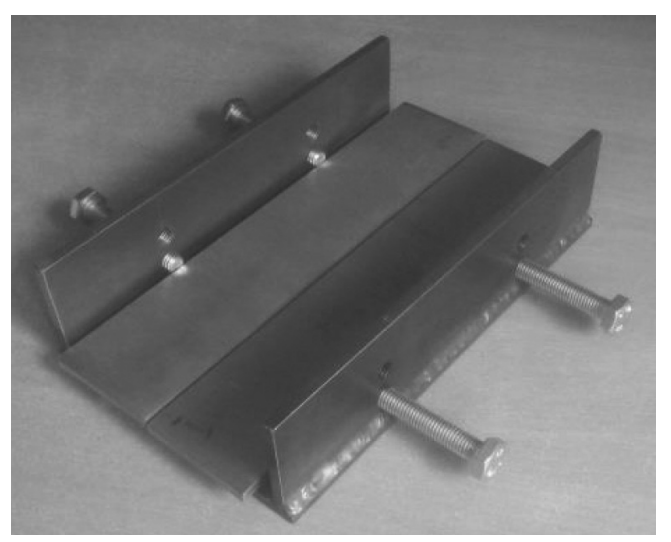

Rys. 3. Przyrząd badawczy na którym umieszczono blachy modelowe Fig. 3. Testing device on which model sheets are placed

\begin{tabular}{|c|c|c|c|}
\hline \multirow{2}{*}{ Proces nr } & \multicolumn{3}{|c|}{ Proces: czas wywoływania } \\
\cline { 2 - 4 } & $\begin{array}{c}\text { Czynniki poddane badaniu } \\
\text { Rodzaj } \\
\text { materiału }\end{array}$ & $\begin{array}{c}\text { Chropowatość } \\
\text { powierzchni, } \\
\mu \mathrm{m}\end{array}$ & $\begin{array}{c}\text { Szerokość } \\
\text { nieciągłości, } \\
\mu \mathrm{m}\end{array}$ \\
\hline 1 & 1 & 1 & 50 \\
\hline 2 & 1 & 5 & 1000 \\
\hline 3 & 1 & 10 & 500 \\
\hline 4 & 1,92 & 1 & 1000 \\
\hline 5 & 1,92 & 5 & 500 \\
\hline 6 & 1,92 & 10 & 50 \\
\hline 7 & 3,4 & 1 & 500 \\
\hline 8 & 3,4 & 5 & 50 \\
\hline 9 & 3,4 & 10 & 1000 \\
\hline
\end{tabular}

Tablica IV. Plan czynnikowy z wartościami

Table IV. Factorial plan with relevant values

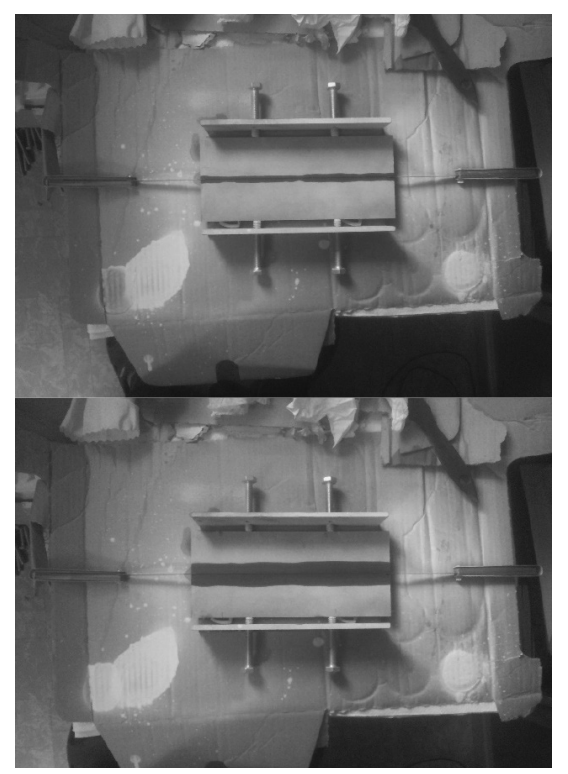

Rys. 4. Rozrost wskazań na blachach modelowych

Fig. 4. Development of indications on model sheets

Tablica V. Końcowe wyniki planu czynnikowego

Table V. Final results of the factorial plan

\begin{tabular}{|c|c|c|c|c|c|c|c|c|}
\cline { 2 - 10 } \multicolumn{1}{c|}{} & \multicolumn{2}{c|}{ Próba numer 1 } & \multicolumn{2}{c|}{ Próba numer 2 } & \multicolumn{2}{c|}{ Próba numer 3 } & \multicolumn{2}{c|}{ Średnia z 3 prób } \\
\hline Proces $\mathrm{nr}$ & $\mathrm{b}, \mathrm{mm}$ & $\mathrm{t}, \mathrm{min}$ & $\mathrm{b}, \mathrm{mm}$ & $\mathrm{t}, \mathrm{min}$ & $\mathrm{b}, \mathrm{mm}$ & $\mathrm{t}, \mathrm{min}$ & $\mathrm{b}, \mathrm{mm}$ & $\mathrm{t}, \mathrm{min}$ \\
\hline 1 & 54,5 & 220 & 56 & 245 & 54,5 & 225 & 55 & 230 \\
\hline 2 & 72,5 & 420 & 73 & 430 & 70,5 & 410 & 72 & 420 \\
\hline 3 & 68 & 395 & 66,5 & 360 & 66,5 & 385 & 67 & 380 \\
\hline 4 & 53 & 405 & 57 & 425 & 55 & 400 & 55 & 410 \\
\hline 5 & 61 & 490 & 58 & 485 & 61 & 525 & 60 & 500 \\
\hline 6 & 54 & 400 & 52,5 & 385 & 52,5 & 385 & 53 & 390 \\
\hline 7 & 67 & 435 & 70 & 465 & 70 & 450 & 69 & 450 \\
\hline 8 & 71,5 & 380 & 71 & 375 & 73,5 & 400 & 72 & 385 \\
\hline 9 & 106 & 730 & 100 & 690 & 100 & 710 & 702 & 710 \\
\hline
\end{tabular}

Uwaga: Kolejność procesów zgodnie z Tablicą IV. b - wymiar największego wskazania; t - czas wywoływania po którym ustał rozrost wskazań 
Wyniki zostały poddane analizie w programie STATISTICA, który posiada narzędzia do planowania doświadczeń czynnikowych, jak i analizy ich wyników. Skorzystano z modułu „Regresja wieloraka”, za pomocą którego można wyznaczyć ilościowe ujęcie związków pomiędzy wieloma zmiennymi niezależnymi, a zmienną zależną. Przed dokonaniem analizy regresji wykonano serię korelacji poszczególnych zmiennych w kilku celach. Pierwszym celem było sprawdzenie, czy predykatory korelują ze zmienną Y, zaś drugim czy nie korelują między sobą. Z uzyskanej korelacji wynikło, iż każda zmienna niezależna koreluje ze zmienną zależną, czyli czasem wywoływania, co potwierdzają uzyskane wartości - 0,575008; 0,$438465 ; 0,602459$. Natomiast zmienne niezależne nie korelują między sobą, co także jest pożądanym wynikiem.

Po otrzymywaniu pozytywnego wyniku korelacji pomiędzy zmiennymi niezależnymi opracowano równanie regresji wielorakiej na podstawie wyników 9 prób przedstawionych w tablicy V.

$$
y=b_{0}+b_{1} \cdot x_{1}+b_{1} \cdot x_{2}+b_{3} \cdot x_{3}+e
$$

gdzie:

y - czas wywoływania, min

$\mathrm{X}_{1}$ - chropowatość powierzchni, $\mathrm{Ra}$

$\mathrm{x}_{2}$ - szerokość nieciągłości, $\mu \mathrm{m}$

$\mathrm{x}_{3}$ - rodzaj materiału,

e - składnik losowy.

Po wykonaniu regresji otrzymano wyniki pokazane na rysunku 5.

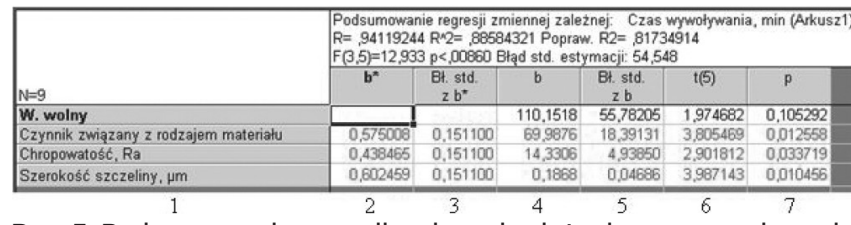

Rys. 5. Podsumowanie regresji zmiennej zależnej: czas wywoływania Fig. 5. Summary of regression of dependent variable: development time

Celem niniejszej pracy było między innymi znalezienie współczynników regresji, które przedstawia kolumna 4 na rysunku 5. Pierwszy wiersz to wartość stała $b_{0}$, a drugi, trzeci i czwarty to współczynniki $b_{1}, b_{2}, b_{3}$. Po podstawieniu współczynników regresji otrzymano równanie:

$$
y=110,1518+69,9876+14,3306+0,1868
$$

Parametr b $b_{1}$ wynosi 69,9876 co oznacza, że jeśli zmieni się materiał ze stali na aluminium, to oczekuje się, że czas wywoływania zwiększy się o około 64 min (proporcja 1:1,92), a przy zmianie ze stali na nikiel o około $168 \mathrm{~min}$ (proporcja 1:3,4). Natomiast parametr $b_{2}$ wynosi 14,3306 , co oznacza, że jeśli wartość chropowatości powierzchni wzrośnie o jedną jednostkę (w tym przykładzie o $1 \mathrm{Ra}$ ), to oczekuje się, że czas wywoływania zwiększy się o 14,3306 min. Z kolei parametr $b_{3}$ wynosi 0,1868 , co oznacza, że jeśli wartość szerokości nieciągłości wzrośnie o jedną jednostkę (w tej pracy o $1 \mu \mathrm{m}$ ), to oczekuje się, że czas wywoływania zwiększy się o 0,1868 min.

W praktyce nie dysponuje się pełną informacją o wszystkich możliwych próbach, dlatego otrzymano funkcję regresji wyliczoną metodą najmniejszych kwadratów w oparciu o dane z 9 prób ujmujących cały zakres wartości zmiennych niezależnych. Ta funkcja regresji, zwana empiryczną, jest aproksymacją regresji w wszystkich możliwych przypadkach. Związane jest to z problemem oceny rozbieżności między wartościami zmiennej zależnej y, a wartościami wyliczonymi z modelu. Różnice, które opisują tą rozbieżność, to tzw. reszty. Im reszty są mniejsze, tym bliżej wartości empirycznej y są wartości przewidywane przez model. Idealnie byłoby, gdyby reszty były równe zeru, ale w praktyce jest to niemożliwe. Zatem potraktowano odchylenie standardowe reszt e jako miarę opisywanej rozbieżności. W statystyce bowiem precyzję estymatora oddaje jego wariancja. W istocie tak też jest - wielkość ta, zwana błędem standardowym estymacji i oznaczana, jako Se, informuje o przeciętnej wielkości odchyleń empirycznych wartości zmiennej zależnej od wartości wyliczonych z modelu (teoretycznych). Dzięki temu parametrowi znana jest miara rozproszenia wyników wokół linii regresji. Odchylenie standardowe reszt mówi więc o stopniu "dopasowania" modelu do danych empirycznych. Im Se mniejsze, tym lepiej dopasowany model. Wartość ta została przedstawiona na rysunku 5 i wyniosła 54,54. Oznacza to, że przewidywane wartości czasu wywoływania różnią się od wartości empirycznych średnio o około 54,54 min. Zatem końcowa postać równania to:

$$
y=110,1518+69,9876+14,3306+0,1868 \pm 54,54
$$

Szacując współczynnik kierunkowy $b_{1}$ na poziomie 69,9876, mylono się średnio o 18,39131. Z kolei, szacując współczynnik kierunkowy $b_{2}$ na poziomie 14,3306 , mylono się średnio o 4,93850. Szacując współczynnik kierunkowy $b_{3}$ na poziomie 0,1868 , mylono się średnio o 0,04686 . Podobnie, szacując wyraz wolny na poziomie 110,1518, mylono się średnio o 55,78205. Dla parametru $b_{1}$ błąd szacunku stanowi około $26 \% \quad(18,39131 / 69,9876=0,26)$, $b_{2}$ - około $34 \%(4,93850 / 14,3306=0,34)$, a $b_{3}$ - około $25 \%(0,04686 / 0,1868=0,25)$. Natomiast dla wyrazu wolnego błąd szacunku wynosi najwięcej, bo około $50 \%$ $(55,78205 / 110,1518=0,50)$. Jeżeli wartość jest bliska 100\% lub większa, precyzja jest bardzo niezadowalająca. Wartości ponad $50 \%$ powinny już zwrócić uwagę na inne oceny modelu. Zatem jedynie wyraz wolny odbiega od oczekiwanych rezultatów. Może to świadczyć o tym, iż jest więcej zmiennych niezależnych, które decydująco wpływają na czas wywoływania, np. ilość naniesionego wywoływacza.

Kolejnym wynikiem do interpretacji był współczynnik determinacji. Jest to liczba z przedziału $\left\langle 0,1>\right.$. $R^{2}$ równe 1 oznacza doskonałe dopasowanie, natomiast wartość $\mathrm{R}^{2}$ równa 0 - brak powiązania między zmiennymi. Współczynnik determinacji podaje, jaka część ogólnej zmienności zmiennej zależnej jest wyjaśniona przez regresję liniową. Wartość $R^{2}$ została podana $w$ arkuszu wyników (rys. 4.) $-w$ górnym wierszu. Wartość ta wynosiła $R^{2}=0,8858$. Zatem równanie regresji wielorakiej wyjaśniało $88,58 \%$ zaobserwowanej zmienności, a nie wyjaśniało 11,42\% zmienności.

Dalszym krokiem otrzymanego modelu była jego weryfikacja. W tym celu stworzono wykresy rozrzutu dla każdej

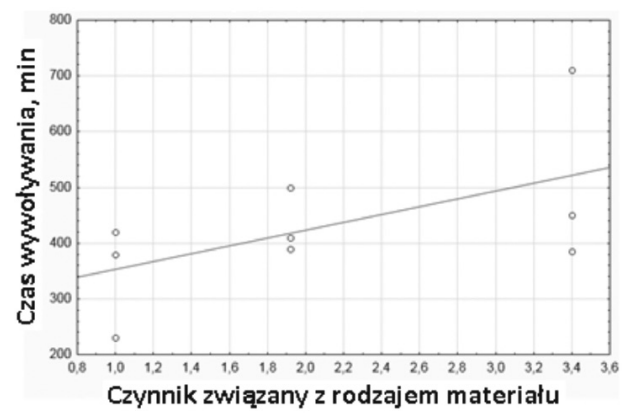

Rys. 6. Wpływ rodzaju materiału na czas wywoływania w badaniach penetracyjnych. Oznaczenia na osi poziomej: 1 - stal, 1,92 - stop aluminium, 3,4 - nikiel

Fig. 6. Impact of the material kind on the development time in penetrant testing. Denotations on horizontal axis: 1 - steel; 1,92 - aluminium alloy; 3,4 - nickel 


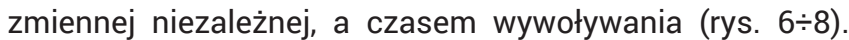
$\mathrm{Na}$ rysunku 6 widać, iż dla stali czas wywoływania jest najkrótszy, dla aluminium pośredni, a dla niklu najdłuższy. Zatem potwierdziły się wcześniejsze badania praktyczne przeprowadzone w niniejszej pracy.

$\mathrm{Na}$ kolejnym wykresie (rys. 7) przedstawiono zależność chropowatości powierzchni szczeliny, w którą wnika pene- trant, a czasem wywoływania. Można zauważyć, iż wraz ze wzrostem chropowatości, wydłuża się czas wywoływania. Spodziewano się, iż czym większa chropowatość powierzchni, penetrant będzie wolniej wydostawał się na

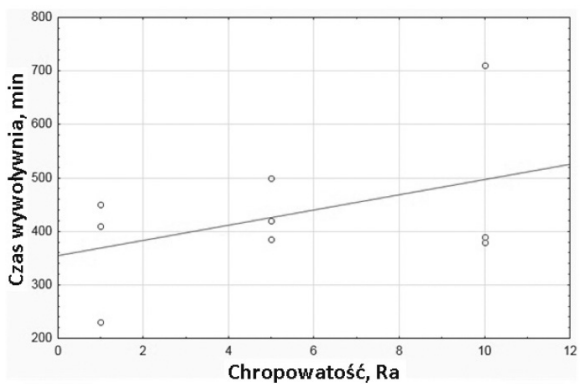

Rys. 7. Wpływ chropowatości powierzchni na czas wywoływania w badaniach penetracyjnych

Fig. 7. Influence of the surface roughness on the development time in penetrant testing powierzchnie, a tym samym wydłuży się czas wywoływania.

Na rysunku 8 przedstawiono zależność czasu wywoływania od szerokości szczeliny. Wraz ze wzrostem szerokości szczeliny wydłuża się czas wywoływania. To także był rezultat, którego się spodziewano, gdyż rosła wówczas objętość penetrantu w szczelinie.

Wszystkie trzy zmienne niezależne dały pozytywne wyniki. W równaniu regresji wielorakiej miały znak dodatni, co także jest prawidłowe, bo świadczy to o zgodności z założeniami teorii. Oprócz weryfikacji merytorycznej przeprowadzono także weryfikację statystyczną.

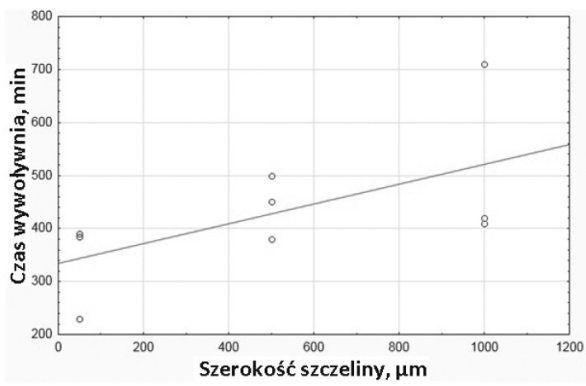

Rys. 8. Wpływ szerokości nieciągłości na czas wywoływania w badaniach penetracyjnych

Fig. 8. Influence of the surface roughness on the development time in penetrant testing

\section{Wnioski}

Na podstawie analizy wyników wykonanych badań sformułowano następujące wnioski:

Istnieje zależność określająca czas wywoływania, będąca funkcją czynników materiałowych. Funkcja ta ma postać: $y=110,1518+69,9876+14,3306+0,1868 \pm 54,54$

Każdy z badanych czynników istotnie wpływa na czas wywoływania w badaniach penetracyjnych. Świadczy o tym korelacja pomiędzy zmiennymi niezależnymi, a zmienną zależną, która wynosi: 0,575008 dla rodzaju materiału (w planie eksperymentu: czynnik związany z rodzajem materiału), 0,438465 dla chropowatości powierzchni oraz 0,6024590 dla szerokości szczeliny. Zatem szerokość szczeliny i rodzaj materiału wpływają w największym stopniu na czas wywoływania, a chropowatość powierzchni w mniejszym, ale także bardzo istotnym.

Wraz ze wzrostem chropowatości powierzchni szczeliny, wydłuża się czas wywoływania, gdyż zmniejsza się zwilżalność i penetrant wolniej przemieszcza się w górę szczeliny. Gdy chropowatość wzrośnie o 1 Ra, to czas wywoływania wydłuża się średnio o około 14 minut.

Wraz ze wzrostem szerokości nieciągłości, wydłuża się czas wywoływania. Prawdopodobnie wynika to z faktu, iż w większej szczelinie może się zmieścić większa objętość penetrantu. Gdy szerokość nieciągłości wzrośnie o $1 \mu$ m, to czas wywoływania wydłuży się średnio o około 0,18 minuty.

Rodzaj materiału (w planie eksperymentu: czynnik związany z rodzajem materiału) wpływa na czas wywoływania, co ujawniło się już na etapie badań praktycznych. Różnice w czasach wywoływania uzyskane w planie eksperymentu są zbliżone do wyników badań praktycznych. Dla stali czas wywoływania jest najkrótszy, dla aluminium o około 64 minut dłuższy, a dla niklu nawet o 168 minut dłuższy względem stali. Wykonując tradycyjne badania (z jednej strony nanoszony penetrant i wywoływacz), czas wywoływania dla stali nie powinien wynosić więcej niż 60 minut. Dla alumi- nium i jego stopów około 200 minut, natomiast dla niklu i jego stopów nawet około 230 minut.

Czasy wywoływania dla poszczególnych materiałów w badaniach pęknięć modelowych znacząco się wydłużyły względem badań praktycznych. Prawdopodobnie jest to spowodowane tym, iż w badaniach praktycznych pęknięcia stanowiły kapilary zamknięte, natomiast w badaniach pęknięć modelowych, przyjętych w planie eksperymentu, szcze- liny były kapilarami otwartymi.

Badania praktyczne wykazały, iż czas penetracji dla aluminium, stali i ich stopów może wynosić zaledwie 10 minut. Dłuższe czasy penetracji nie wpłynęły na wyniki. Natomiast dla niklu i jego stopów zaleca się, aby czas penetracji wydłużyć nawet do 120 minut, gdyż wpływa to na czas wywoływania, jak i wielkość wskazań. Także dla stali austenitycznych zaleca się wydłużenie czasu penetracji w zależności od ilości procentowej niklu w składzie.

Otrzymane równanie regresji wielorakiej nie wyjaśnia około 11 \% zmienności, co może świadczyć o tym, iż jest jeszcze jedna bądź kilka zmiennych niezależnych, które wpływają na czas wywoływania, np. ilość naniesionego wywoływacza, temperatura.

\section{Literatura}

[1] Czuchryj J., Sikora S. Podstawy badań penetracyjnych wyrobów przemysłowych, Instytut Spawalnictwa, Gliwice 2007.

[2] Ferenc K., Ferenc J. Konstrukcje spawane: połączenia, Wydawnictwa Naukowo-Techniczne, Warszawa 2009.

[3] Hedegard J., Wahlsten J., Randelius M., i inn. Influence of internal micofissures on fatigue life, Weld Word, t.53, nr 9/10, 2009.

[4] Czuchryj J., Dębski E. Wymagania odbiorowe konstrukcji spawanych na podstawie badań nieniszczących według norm europejskich, Biuletyn Instytutu Spawalnictwa, nr 4, 1999. 